Kåre Haugan (corresponding author) is a professor (dosent) at the Nord University, Norway. He has a Ph.D in molecular biology and is involved in research and teaching within field biology and chemistry at the teacher education program (master degree). His research interests are also addressing inquiry based teaching, the learning of species in biology (field biology), ethnobotany and outdoor education.

Anna Marie Holand is an associate professor at the Nord University, Norway. She has a Ph.D in biology, in the field of evolutionary biology and statistics, and she is working at the teacher education program (master degree). She is involved in research and teaching within biological statistics, ecology, outdoor education, sustainable development and school garden as a learning arena.

\title{
KÅRE HAUGAN
}

Nord universitet, Norway

kare.haugan@nord.no

ANNA MARIE HOLAND

Nord universitet, Norway

anna.m.holand@nord.no

\section{Lærerstudenters misoppfatninger og læring om kjemiske reaksjoner}

\begin{abstract}
This study has addressed misconceptions and the learning process of chemical reactions. 14 student teachers performed a written test consisting of 28 multiple choice questions and after participating in five chemistry classes the students were interviewed individually focusing on misconceptions and experienced learning events. Several misconceptions and hindrances for the learning of chemical reactions were identified. Some of these are previously identified, but two were more surprising; Three out of 13 students were confused when switching between the terms chemical "reaction" and chemical "change", a confusion generated by a chemistry textbook. In addition, one student mixed up the symbolic meaning of the letter " $\mathrm{C}$ " in $\mathrm{NaCl}$ to $\mathrm{C}$ for the element carbon. Another student learned the profound difference between two states of a substance when the symbols (aq) and (I) were used to differ between "dissolved in water" and "liquid". Finally, the students identified dialogue and laboratory work as important for their learning of chemical reactions.
\end{abstract}

\section{INNLEDNING}

\section{Kjemi er en del av naturfag i norsk skole}

Kjemi er en sentral del av naturfaget i både grunnskole og i videregående skole, og kjemiske reaksjoner er det mest sentrale temaet i kjemifaget. Denne studien legger til grunn forståelsen av begrepet «kjemiske reaksjoner» som prosesser der det dannes nye stoffer, nye kjemiske forbindelser. Gjeldende læreplan for norsk grunnskole har flere kompetansemål som innbefatter kjemiske reaksjoner og forståelse av disse (Udir, 2019a). Etter 7. årstrinn finner man blant annet kompetansemålet «elev- 
ene skal kunne gjennomføre forsøk med ulike kjemiske reaksjoner og beskrive hva som kjennetegner dem», og etter 10. årstrinn ligger kompetansemålet «eleven skal kunne planlegge og gjennomføre forsøk med påvisningsreaksjoner, separasjon av stoffer i en blanding og analyse av ukjent stoff». Kjemiske reaksjoner er derfor et tema i naturfag som lærerne skal undervise, og økt kunnskap om og bevissthet rundt dette er derfor nyttig for naturfaglæreren. Temaet er sentralt i skolens naturfag og er også sterkt framme i ny læreplan (Fagfornyelsen) som ble implementert i norsk grunnskole høsten 2020 (Udir, 2019b). Manglende forståelse for kjemiske reaksjoner er blant annet vist å være en årsak til at elever i skolen i liten grad klarer å oppnå god forståelse for karbonets kretsløp (Düsing, Asshoff \& Hammann, 2019). En forståelse av karbonets kretsløp i naturen innebærer erkjennelsen av at atomer går over fra ett stoff til et annet (kjemiske reaksjoner).

Studenter har vanligvis med seg en form for forforståelse av kjemiske reaksjoner inn i en læringssituasjon. Forforståelsen kan ha ulik grad av slagside mot hva som er allment aksepterte naturvitenskapelige forklaringer, og umodne ideer som utvikles uten forankring i naturvitenskap er ikke nødvendigvis feil, men alternative eller originale i sin form (Barke, Hazari \& Yitbarek, 2009). Begrepet misoppfatninger blir her brukt om feilforståelser som har oppstått gjennom formelle og/eller uformelle læringsprosesser, og uheldige valg av læringstilnærminger kan være med på å skape faglige forståelser som er feil (Barke et al., 2009). Forståelse av og innsikt i studenters misoppfatninger gir læreren en mulighet til å forstå studentens ståsted i læringsprosessen, noe som igjen kan anvendes til å skape en best mulig læringssituasjon for studenten. Ved å øke kunnskapen om studenters misoppfatninger kan man legge til rette for bedre undervisning samtidig som studentene blir bevisstgjort problematikken. Studenter kan i neste instans utvikle og forbedre egen undervisningspraksis gjennom økt forståelse og bevissthet om elevers forestillinger. Utvikling av undervisningsstrategier der en lærer bevisst utfordrer misoppfatninger hos elever og studenter kan være fruktbare (Taber, 2002). God, oppsummerende litteratur om misoppfatninger innen kjemifaget er tidligere publisert blant annet av Barke et al. (2009), Kind (2004) og Taber (2002). I denne artikkelen benyttes begrepet misoppfatninger og ikke forforståelse da informantene i studiet (lærerstudenter) har bak seg flere år med naturfag- og kjemiundervisning.

\section{Vanlige misoppfatninger om kjemiske reaksjoner}

Når det gjelder kjemiske reaksjoner er det vanlig å forveksle kjemiske og fysiske prosesser. En kjemisk reaksjon defineres ut fra at ett eller flere utgangsstoffer (reaktanter) omdannes til ett eller flere nye stoffer (produkter) (Hannisdal \& Ringnes, 2013). Særlig blir endringer i aggregattilstand ofte forvekslet med en kjemisk reaksjon. Et eksempel på dette er at når vann kokes og omdannes til vanndamp så kan det mistolkes til å være en kjemisk reaksjon. Utsagn som kan forekomme er at vannet blir til «luft» eller «oksygengass og hydrogengass» (Barke et al., 2009).

At masse forsvinner gjennom en kjemisk reaksjon er også en vanlig misoppfatning der eksempler på utsagn fra studenter kan være at «stearinlyset forsvant etter hvert» ved forbrenning (Kind, 2004). At massen av reaktanter og massen av produkter i en kjemisk reaksjon er den samme er noe som det bør være fokus på innen kjemiundervisning. I tillegg er energi og kjemiske reaksjoner noe som studenter lett danner seg misoppfatninger om, og en vanlig forestilling er at energi blir «brukt opp» i f.eks. forbrenningsreaksjoner (Barke et al., 2009). Her er det viktig å poengtere i undervisningen at energi kun går over fra en form til en annen (energioverføring) og at energimengden er konstant. Det må energi til for å bryte kjemiske bindinger, og energi frigjøres ved dannelse av nye bindinger under en kjemisk reaksjon. Noe av misoppfatningen ligger $i$ at studenter lettere forestiller seg at energi frigjøres når bindinger brytes enn at energi frigis som et «overskudd» etter at nye bindinger blir dannet.

Ett annet eksempel på en misoppfatning er når man løser $\mathrm{NaOH}$ i vann så frigis det varme, løsningen blir elektrisk ledende og pH i løsningen øker. Dette er likevel ikke en kjemisk reaksjon da ionene $\left(\mathrm{Na}^{+}\right.$ og $\mathrm{OH}^{-}$) går fra å være i en gitterstruktur (fast stoff) til å være omgitt av vannmolekyler. Dette kan mistolkes for å være en kjemisk reaksjon da observerbare kjennetegn som varmeavgivelse, endring i elektrisk ledningsevne og endring i pH kan lede tankene i den retning. 


\section{Begrepsforståelse og språk i læring om kjemiske reaksjoner}

Ord har ulik betydning i hverdagen og i en naturfaglig kontekst, og det kan gi spillerom for misforståelser og grunnlag for dannelse av misoppfatninger (Gabel, 1999). Det er viktig at læreren er klar over mulige feiltolkninger av begreper og forebygger dette ved klare begrepsoppganger gjennom undervisningen. Et eksempel på norsk er at vi kan si at kaffen er sterk i hverdagsspråket, men som naturfaglig beskrevet kunne ha blitt beskrevet som at kaffen er konsentrert. Drar man denne forståelsen av begrepet inn i teori om syrer og baser kan man få problemer med å innarbeide begrepene sterk og svak syre kontra konsentrert og fortynnet syre.

Noen begreper må man arbeide kontinuerlig med gjennom hele kjemistudiet for å oppnå en dypere og mer konseptuell forståelse (de Vos, van Berkel \& Verdonk, 1994). Dette gjelder for eksempel begreper som molekyler, stoff, løsninger og mol. En studie av Håland (2010) viste at også norske lærerstudenter har problemer med begrepene stoff og faseoverganger.

En annen utfordring for studenter er forholdet mellom makronivå (det vi kan se, berøre og lukte), mikronivå (atomer, molekyler og kjemiske strukturer) og representasjonsnivå (symboler, formler og ligninger) (Johnstone, 1991). Det er ikke uvanlig at alle tre nivåene blir introdusert samtidig for studenter i kjemiundervisning noe som gjør det svært krevende å få forståelse for begrepene (Barke et al., 2009). Det er i tillegg vanlig i undervisning at læreren går direkte fra makronivå til representasjonsnivå noe som medfører at elever har liten mulighet til å følge konseptovergangen (Gabel, 1999). I tillegg ser den primære barrieren for å forstå kjemi ut til å være at kjemiundervisningen ofte ligger på det mest abstrakte nivået; symbolspråket. Undervisning som vektlegger (og tester for) kjemibeskrivelse på symbolnivå med ligninger og tall ser heller ikke ut til å fremme læring av mer komplett og dyp forståelse av kjemibegreper (Phelps, 1996). Et vanlig problem er også at egenskaper på makronivå (smør er mykt) feilaktig blir overført til mikronivå («smørmolekyler» er myke) (Jong \& Taber, 2014).

Praktisk arbeid i kjemi (eller laboratorieforsøk) er svært vanlig i kjemiundervisning. Det har vært argumentert mye for at praktisk arbeid med fordel kan ha en mer utforskende vinkling for å fremme bedre læring (Minner, Levy \& Century, 2010). En av grunnene til at kjemi kan oppfattes som vanskelig er at læreren forventer at observasjoner gjort på makronivå under laboratoriearbeid skal forklares på mikronivå/symbolnivå av studenter (Gabel, 1999). En annen faktor er at når studenter ikke har kjennskap til eller ikke gjenkjenner navnet på stoffer det jobbes med, så blir lærestoffet abstrakt og kunnskap på mikro- og makronivå blir ikke koblet sammen (Phelps, 1996). Tradisjonelt laboratoriearbeid ser derfor bl.a. av ulike grunner ikke ut til å være en effektiv strategi for å bygge og styrke en dypere begrepsforståelse, men kan være gunstig for å lære naturvitenskapelige arbeidsmåter, trene observasjon, praktiske ferdigheter, logisk resonnering, positive holdninger etc. (Abrahams \& Millar, 2008).

\section{Undervisning som styrker læring}

Undervisningen i kjemi blir bedre dersom man tar hensyn til misoppfatninger ved planlegging og implementering av undervisning, men en studie viser at ni av ti kjemilærere ikke kjenner til misoppfatninger eller ikke planlegger å korrigere misoppfatninger gjennom undervisningen (Gabel, 1999). En annen studie viser at kjemilærere på ungdomsskolenivå («secondary school») kan kjenne til misoppfatninger, men har ikke kunnskap om hva som kan være kilden til slike misoppfatninger (Ilyas \& Saeed, 2018). Det er også viktig for læringen at undervisningen gjennomføres slik at den blir mer kontekstbasert og meningsfull for studentene (Jong \& Taber, 2014). Eksempler på kontekstualisering er å forankre undervisninga til dagliglivet (f.eks. mat, næringsstoffer og helse), samfunnsdebatter (dannelse av drivhusgasser), potensiell profesjonsutøvelse (kvantifisering av eksosgasser fra forbrenningsmotorer) og aktuelle tema for å øke naturvitenskapelig «literacy» (kommunal behandling av drikkevann). Utforskende tilnærming i det praktiske arbeidet ser ut til å gjøre læringen mer helhetlig der både 
begrepslæring og hypotetisk-deduktiv arbeidsmåte kan bli ivaretatt gjennom god veiledning og støtte av læreren («scaffolding») (Kolstø, 2018).

En studie viser at en effektiv strategi for å korrigere misoppfatninger i kjemi hos 17-18 åringer er å undervise ved aktiv bruk av «konstruktivisme og analogier» (Adzape \& Akpoghol, 2015). Her sikter forfatterne til at elevene driver aktiv kunnskapsbygging gjennom aktivitet og subjektive prosesser, der analogier systematisk blir benyttet i undervisningen for å bedre faglig forståelse.

Jaber og BouJaoude (2012) gjennomførte kjemiundervisning hos 16-åringer med økt fokus på overgangene og samspillet mellom mikro-, makro- og symbolnivå, og de viste at dette ga et bedre faglig resultat sammenlignet med en kontrollgruppe. Gjennom dette arbeidet hadde de økt fokus på symbolske representasjoner som diagrammer, illustrasjoner og tegninger etc. og økt fokus på modeller som tar for seg usikkerhet, begrensninger og kreativitet. Det ble også lagt vekt på å lære om modellers forklaringskraft.

\section{Forskningsspørsmål}

Det har blitt utført noe forskning på misoppfatninger innen realfagene hos lærerstudenter tidligere. Noen eksempler på dette er innen temaet grenseverdier i matematikk (Kula \& Güzel, 2014), økologi i biologifaget (Butler, Simmie \& Grady, 2015), masse og gravitasjon i fysikk (Gönen, 2007), geologisk tid innen geologifaget (Teed \& Slattery, 2011) og begreper i kjemi (Calik \& Ayas, 2005). Misoppfatninger innen kjemifaget i utdanningssammenheng har hatt mest fokus på nivå grunnskole og videregående skole eller ved studier av realfagsstudenter på universitets- og høgskolenivå. Forskning på kjemilæring og forståelse av kjemiske reaksjoner hos studenter i dagens grunnskolelærerutdanning er derimot mangelfull. Et fokus på disse studentene kan tjene et dobbelt formål der det ene er å bedre læring av kjemi hos lærerstudentene, og det andre er en mulig overføringsverdi til studentenes egen praksis der økt kunnskap om misoppfatninger kan styrke undervisning av elever i grunnskolen. I vår studie ønsket vi derfor å fokusere på følgende forskningsspørsmål:

1. Hva er enkelte lærerstudenters misoppfatninger av «kjemiske reaksjoner»?

2. Hvilke refleksjoner gjør disse studentene seg om egne misoppfatninger og egen læring om kjemiske reaksjoner etter å ha gjennomgått undervisning om dette temaet?

\section{METODE}

\section{Norsk skolesystem og lærerutdanning}

Den norske grunnskolen er 10-årig (alder 6-16 år som utgjør 1.-10. trinn). Disse 10 årene deles så inn $\mathrm{i}$ «barneskolen» (1.-7. trinn), og «ungdomsskolen» (8.-10. trinn) (Udir, $2019 \mathrm{a}, \mathrm{b})$. Deretter kommer videregående skole (VGS) som varer 3-4 år der det første året inneholder ett naturfagemne som er likt for alle elever som skal kvalifisere seg for studier på universitet eller høgskole («studieforberedende»). Det tilsvarende naturfagemnet for de yrkesfaglige studieretningene er redusert i omfang og har til dels et annet innhold. Elevene på VGS kan etter første studieår velge fordypningskurs i kjemi (Kjemi 1 og Kjemi 2) eller kjemiprosessfag som en yrkesfaglig studieretning.

Den norske utdanningen for grunnskolelærere innførte høsten 2017 femårig master som standard. Grunnskolelærerutdanningen har to ulike studieløp der man kan kvalifisere seg for å undervise for grunnskolens 1.-7. trinn eller 5.-10. trinn. I Norge er det ikke formelle krav om utdanning i naturfag for å undervise i naturfaglige tema i barneskolen, mens for å undervise i naturfag i ungdomsskolen er det krav om minimum 30 ects naturfaglig utdanning.

\section{Utvalg av informanter}

En kvalitativ metode med semistrukturerte intervju og flervalgsoppgaver ble benyttet for å skaffe økt kunnskap om grunnskolelærerstudenters misoppfatninger av kjemiske reaksjoner og deres refleksjoner rundt egen læring. Et utvalg naturfagstudenter ved grunnskolelærerutdanningen for 5.-10. 
årstrinn ble valgt som informanter. Utvalget besto av 14 naturfagstudenter fra to ulike klasser som sa seg villig til å delta i studien, sju jenter og sju gutter. Formelle forkunnskaper i kjemi varierte hos begge kjønn fra grunnleggende (kun Naturfag 1 fra første år i videregående skole - VGS), middels (Kjemi 1 fra VGS) til høye forkunnskaper (Kjemi 2 fra VGS). En spredning i forkunnskaper hos informantene øker potensialet for å identifisere flere ulike typer misoppfatninger om kjemiske reaksjoner.

\section{Innhenting av empiriske data}

Studentene ble involvert i studien rett før oppstart av undervisning om kjemiske reaksjoner. Data ble samlet inn ved først å kartlegge misoppfatninger hos studentene ved at de uten hjelpemidler svarte skriftlig på 28 flervalgsoppgaver om kjemiske reaksjoner. Eksempler på oppgaver er vist i resultatdelen av denne artikkelen. Spørsmålene var hentet fra Haug (2017) og fra PISA- og TIMSS-studier (PISA, 2017; TIMSS, 1995, 2007, 2015, 2017). Seks oppgaver var tilpasset mellomtrinnet i grunnskolen (5.-7. trinn) (Haug, 2017), mens resten av oppgavene var tilpasset 15-åringer (9. trinn) (PISAog TIMSS-oppgaver). Oppgavene ble plukket ut blant de frigitte spørsmålene der temaet var kjemiske reaksjoner, og disse oppgavene ble inndelt i sju kategorier (tabell 1). Antall spørsmål i hver kategori var i hovedsak et resultat av hvilke oppgavetyper som var frigitte fra PISA- og TIMSS-studiene.

Tabell 1. Oversikt over sju ulike kategorier av spørsmål som ble benyttet.

\begin{tabular}{|l|c|}
\hline Kategori spørsmål om kjemiske reaksjoner & Antall spørsmål \\
\hline Forståelse av begrepene grunnstoff, reaktant og produkt & 7 \\
\hline Forståelse av andre begreper & 6 \\
\hline Skille endring i aggregattilstand og kjemisk reaksjon & 5 \\
\hline Bevaring av masse i kjemiske reaksjoner & 4 \\
\hline Kjennetegn på kjemiske reaksjoner & 3 \\
\hline Energi i kjemiske reaksjoner & 2 \\
\hline «Avansert forståelse» & 1 \\
\hline
\end{tabular}

Etter å ha besvart flervalgsoppgavene fikk studentgruppen undervisning om kjemiske reaksjoner i fem dobbeltimeøkter fordelt på fire uker. Undervisningen omfattet både teori og praktiske forsøk. Teorigrunnlaget tok utgangspunkt i kapittel 6 og 7 i «Kjemi for lærere» som omhandler kjemiske reaksjoner og hovedtyper av kjemiske reaksjoner. Ett av de praktiske forsøkene var et undervisningsopplegg med reaktantene $\mathrm{NaHCO}_{3}, \mathrm{CaCl}_{2}$ og fenolrødtløsning som blandes (Hannisdal \& Ringnes, 2013). Observerbare tegn på at det skjer en kjemisk reaksjon er at fargen på indikatorløsningen endres fra rødt til gult (det blir surt), det dannes en gass $\left(\mathrm{CO}_{2}\right)$, og det avgis varme (en eksoterm reaksjon).

Etter undervisningsperioden gjennomgikk studentene individuelle intervju på 15-35 minutter. Intervjuene var semistrukturert, og spørsmålene ble forsøkt stilt på en åpen og nøytral måte (Kvale \& Brinkmann, 2015). I første del av intervjuet ble studentene oppfordret til å reflektere over sin egen læring om kjemiske reaksjoner med fokus på endring av forståelse av kjemiske reaksjoner. Studentene skulle prøve å knytte slike endringer til spesielle erfaringshendelser under kjemiundervisningen. Andre del av intervjuet var individuelt tilpasset slik at flervalgsoppgavene som var besvart av en gitt student dannet grunnlag for andre del av intervjuet med denne studenten. Informantene fikk studere sitt eget svarskjema og påpekt spørsmål der de hadde svart feil. De ble så oppfordret til refleksjon gjennom å utdype, forklare og evt. rette opp sine egne opprinnelige svar uten å få oppgitt hva som var det korrekte svaret. 


\section{Analyse av data}

Det ble gjort opptak av alle intervjuene, og viktige og interessante deler av intervjuene ble transkribert i programmet NVivo og så gjort gjenstand for åpen koding. Kodingen av transkripsjonene var induktiv og iterert, og var fundert i Braun og Clarke (2006) sin tematiske analyse. Innledende koding hadde en induktiv tilnærming, og videre analyse ble å rekode, sortere og kategorisere disse utsagnene gjennom en iterert prosess. For å optimalisere analysen av resultatene, så ble transkripsjonene, kodingen og kategoriseringen gjennomgått og diskutert i felleskap av forfatterne (Kvale \& Brinkman, 2015). Spesielt ble transkriberingen av sitater som er benyttet i teksten nøye sjekket for å kvalitetssikre at siteringen er korrekt gjengitt.

Ett eksempel på en kodingssyklus er at koden «kokepunkt» (en av 53 initielle koder) først ble satt som underkode under «fysiske-kjemiske egenskaper» sammen med «surhet» og «tetthet». Tekstinnholdet i disse tre havnet til slutt som referanser i koden «fysiske-kjemiske egenskaper», en av 6 koder i kategorien «misoppfatninger». Et annet eksempel er at den initielle koden "tidsbruk» ble satt som en av fem underkoder til koden «praktisk arbeid». Innholdet i «tidsbruk» ble etter gjentatte bearbeidinger plassert som tekstreferanse i koden «praktisk arbeid» under kategorien «læringshendelser». Den første kodingen resulterte i 53 koder på tre hierarkiske nivå. Etter gjentatt bearbeidelse av kodene ble disse redusert til 16 koder på to nivå som til slutt ble samlet i de tre kategoriene «begreper», «misoppfatninger» og «læringshendelser» (øverste nivå i hierarkiet) (tabell 2).

Tabell 2. Oversikt over tre overordnede kategorier med tilhørende koder etter gjentatt sortering, rekoding og kategorisering.

\begin{tabular}{|l|l|l|l|}
\hline Kategori & \multicolumn{1}{|c|}{ Begreper } & \multicolumn{1}{|c|}{ Misoppfatninger } & \multicolumn{1}{c|}{ Læringshendelser } \\
\hline Koder & Atomer-molekyler & Aggregattilstand & Dialog \\
& Reaksjon-forandring & Bevaring av masse & Forberede undervisning \\
& Blanding av begreper & Blanding - reaksjon & Heftet \\
& Upresise begreper & Fysiske-kjemiske egenskaper & Lærebok \\
& & Kjennetegn på reaksjon & Praktisk arbeid \\
& & Symbolforståelse & Repetisjon \\
\hline
\end{tabular}

Kodene i kategorien begreper inneholder ulike former for misforståelser av begreper (tabell 2). Særlig ble begrepsblandingen atomer-molekyler og forståelsen av ordene reaksjon og forandring framtredende i intervjuene. I kategorien misoppfatninger om kjemiske reaksjoner representerte kodene en bred variasjon av ulike misoppfatninger fra sammenblanding med endring av aggregattilstand og manglende forståelse for massebevaring til en noe mer overraskende feiltolkning av symboler. Kodene i kategorien læringshendelser viser et mangfold av situasjoner og arbeidsøkter som studentene peker på som viktige for deres læring om temaet. Et spenn fra læring gjennom dialog til erfaring med praktisk arbeid ble gjennom intervjuene beskrevet av studentene.

All data ble anonymisert og behandlet etter Norsk senter for forskningsdata (NSD) sin standard (godkjent av NSD i desember 2017). 


\section{RESULTAT}

\section{Oversikt over svarfordeling fra spørreskjemaene}

Kartleggingen av forkunnskapene til de 14 studentene ble gjort ved hjelp av spørreskjemaer med flervalgsoppgaver som inneholdt 28 ulike spørsmål. For å få et bilde av hva som var mest dominerende av misoppfatninger blant de 14 studentene ble det valgt å fokusere på spørsmål som ble feilbesvart av minst tre studenter. Det utvalget peker ut sju av 28 flervalgsoppgaver, og disse faller inn under kategoriene begreper (fire ulike spørsmål feilbesvart av 10 studenter), endring i aggregattilstand vs. kjemisk reaksjon (ett spørsmål feilbesvart av fire studenter) og forståelse av grunnstoff (ett spørsmål feilbesvart av tre studenter) (se tabell 1). I tillegg ble ett spørsmål som innebar mer «avansert forståelse» feilbesvart av ni studenter. Disse fire temaene dominerte innen manglende kjemiforståelse til studentgruppen , og alle disse sju spørsmålene var hentet fra TIMSS- eller PISAundersøkelser opprinnelig tilpasset 15-åringer (9. trinn) i grunnskolen.

\section{Feilbesvarte spørsmål og refleksjoner knyttet til disse}

De sju utvalgte spørsmålene sammen med studentenes tilhørende refleksjoner rundt egne feilsvar er presentert under. En gjennomgang av spørsmål som var feilbesvart av tre studenter eller mer viste at det temaet som var mest feilbesvart var knyttet til forståelse av begreper (fire spørsmål) Ett av disse med svarfordeling er vist i tabell 3 :

Tabell 3. Spørsmålet i spørreskjemaet og svarfordeling for et spørsmål hentet fra TIMSS (2015). Korrekt alternativ er uthevet.

\begin{tabular}{|c|c|c|c|c|c|c|c|c|}
\hline \multicolumn{3}{|c|}{$\begin{array}{l}\text { For hver egenskap i lista nedenfor, kryss av for å vise om egenskapen } \\
\text { er en fysisk egenskap eller en kjemisk egenskap. }\end{array}$} & \multirow{2}{*}{\multicolumn{6}{|c|}{$\begin{array}{l}\text { Fordeling av feil svar (o) fordelt } \\
\text { på seks studenter, en kolonne pr. } \\
\text { student. }\end{array}$}} \\
\hline \multirow[b]{2}{*}{ Reagerer med vann } & \multirow{2}{*}{$\frac{\text { Fysisk egenskap }}{0}$} & \multirow{2}{*}{$\frac{\text { Kjemisk egenskap }}{14}$} & & & & & & \\
\hline & & & & & & & & \\
\hline Kokepunkt & 10 & 4 & & & 0 & o & o & o \\
\hline Surhet & 4 & 10 & o & 0 & & & o & o \\
\hline Tetthet & 12 & 2 & & & & 0 & & 0 \\
\hline
\end{tabular}

Alle studenter hadde valgt riktig på første del ved å koble «reagerer med vann» til en kjemisk egenskap. Det kan skyldes at verbet «reagere» assosieres til «kjemi». Av de 14 studentene var det seks studenter som tilsammen ga 10 feilavkrysninger på resten av oppgaven som etterspør forståelse av forskjellen mellom begrepene fysiske og kjemiske egenskaper. Av disse sto én student for 3 gale avkrysninger og to studenter hadde to gale avkrysninger hver. Studenten med 3 gale avkrysninger hadde middels kjemifordypning (Kjemi 1) fra videregående skole, men de to som hadde to gale avkrysninger hadde ingen fordypning i kjemi eller full fordypning i kjemi (Kjemi 2) fra videregående skole. Det så ikke ut til at forkunnskaper fra VGS hadde sikret en grunnleggende begrepsforståelse hos disse, men det kan synes som undervisningen om kjemiske reaksjoner i denne studien har generert en gryende forståelse for ulikheten mellom de to ulike begrepene. Dette kan illustreres med et utsagn fra en student med middels forkunnskaper som opprinnelig hadde svart feil på spørsmålet i tabell 3:

Kokepunkt og tetthet er noe stoffene har fra før - før de reagerer.

Her trekker studenten opp et skille mellom de to begrepene fysiske og kjemiske egenskaper ved å knytte verbet reagere til kjemiske egenskaper.

Et annet spørsmål relatert til begreper var et spørsmål der halvparten av studentene hadde svart galt (tabell 4). 
Tabell 4. Svarfordeling for et spørsmål hentet fra TIMSS (1995). Korrekt alternativ er uthevet.

\begin{tabular}{|l|c|}
\hline \multicolumn{2}{|l|}{ Dyr består av mange atomer. Hva tror du skjer med atomene etter at dyret er dødt? } \\
\hline Svaralternativ & Antall svar \\
\hline a. $\quad$ Atomene slutter å bevege seg. & 0 \\
\hline b. $\quad$ Atomene går tilbake til omgivelsene. & 7 \\
\hline c. $\quad$ Atomene deler seg i mindre deler og blir så satt sammen til andre atomer. & 7 \\
\hline d. $\quad$ Atomene eksisterer ikke lenger når dyret er dødt. & 0 \\
\hline
\end{tabular}

Halvparten av studentgruppen har her landet på feil alternativ (tabell 4). En student med grunnleggende forkunnskaper og med galt svar kommenterte dette under intervjuet:

Jeg tror jeg egentlig har tenkt at det var snakk om noe større enn atomene da. Kanskje molekyler som delte seg i mindre deler og blir satt sammen på nytt.

Denne studenten har etter undervisningsperioden kommet godt videre i sin begrepsforståelse og ser at utsagnet (svaralternativ c) stemmer dersom man benytter begrepet molekyler istedenfor atomer. En annen student med gode forkunnskaper og feil svar på oppgaven kommenterte dette på følgende måte:

Det jeg tror jeg har tenkt der er at med nedbryting av dyr og alt sånt - at det går fra hverandre, men det går jo tilslutt tilbake til omgivelsene. Det er jo på en måte det, men kanskje tenkt litt. Tenke den her prosessen med nedbrytning og at ting deler seg og at så forsvinner det ned i jorda og så vokser det opp noen planter og litt sånne ting da.

Informanten utrykker gjennom utsagnet svært stor utrygghet med hensyn til fagbegreper og skjuler gjentatte ganger manglende begrepsapparat med ordet «det» og «ting» om vev, molekyler, mineraler og planter/dyr. Studenten hadde gode formelle forkunnskaper (Kjemi 2 VGS), men det ser ikke ut til at det har vært tilstrekkelig, og undervisning om kjemiske reaksjoner ser heller ikke ut til å ha styrket begrepsapparatet. Sammenhengen mellom makronivået (dyret) og mikronivået (atomer) er svært uklar, og koblingen mellom to av kjemiens tre dimensjoner er ikke etablert (Johnstone, 1991). Forståelsen av mikronivået ser også ut til å være ufullstendig.

Ett tredje spørsmål under temaet begreper var feilbesvart av tre studenter og ubesvart av en student (tabell 5).

Tabell 5. Svarfordeling fra 13 studenter der spørsmålet var hentet fra TIMSS 2007 (en student besvarte ikke spørsmålet). Korrekt alternativ er uthevet.

\begin{tabular}{|l|c|}
\hline \multicolumn{2}{|l|}{ Hvilket av alternativene nedenfor er IKKE et eksempel på en kjemisk forandring? } \\
\hline Svaralternativ & Antall svar \\
\hline a. $\quad$ Is som smelter & 10 \\
\hline b. $\quad$ Sølv som mørkner. & 0 \\
\hline c. $\quad$ Fyrstikk som brenner. & 3 \\
\hline d. $\quad$ Planter om råtner. & 0 \\
\hline
\end{tabular}

Hensikten med dette spørsmålet var å finne ut om informanten vet forskjell på en kjemisk reaksjon og endring i aggregattilstand. For de studentene som svarte feil var ikke forskjellen så åpenbar, og dette kan illustreres med følgende utsagn fra en student med gode forkunnskaper: 
Jeg tror jeg egentlig har tenkt motsatt. Fordi at jeg tror jeg ble litt forvirret av det «forandringordet».

Videre så svarte en annen student med grunnleggende forkunnskaper følgende i intervjuet:

Der og var jeg jo litt gjetting da. Fordi jeg visste ikke hva en kjemisk forandring var.

Begge disse studentene svarte feil med utgangspunkt i at de ikke skjønte innholdet i begrepet «forandring» i denne konteksten. De ble begge forvirret av selve ordbruken i spørsmålet, og hadde man benyttet begrepet «reaksjon» istedenfor hadde kanskje flere forstått hva det ble spurt om. Den samme forvirringen dukket opp når studentene skulle gjøre rede for hva de tenkte når de feilbesvarte et spørsmål der begrepet «forandring» inngår i begge svaralternativer: «Kjemisk forandring eller fysisk forandring». En student kommenterer denne usikkerheten helt eksplisitt:

Så kjemisk forandring vil si at det har skjedd en kjemisk reaksjon?

Det går fram at ordet «forandring» i spørsmålet var forvirrende når det ble knyttet til begrepet «kjemi», og tre studenter svarte feil fordi de ikke forsto selve spørsmålet.

Studenten som ble forvirret av «forandring»-ordet forklarte videre hva som var opprinnelsen til forvirringen:

.... Da jeg leste i kjemiboka dagen før tror jeg. Og der sto det et eller annet - forandring - forandret tilstand (....). Jeg tror det var det som sporet meg av.

Her kunne opprinnelsen til begrepsforvirringen spores direkte tilbake til læreboka. Studenten forsto ikke spørsmålet, og feil avkrysning ble et resultat av gjetting fra studentens side.

Ett spørsmål som ble feilbesvart av fire studenter hadde fokus på forskjellen mellom kjemiske reaksjoner og endring i aggregattilstand (tabell 6).

Tabell 6. Svarfordeling fra 14 studenter for et spørsmål hentet fra TIMSS (1995). Korrekt alternativ er uthevet.

\begin{tabular}{|l|c|}
\hline \multicolumn{2}{|l|}{ Hvilken av hendelsene er et eksempel på en kjemisk reaksjon? } \\
\hline Svaralternativ & Antall svar \\
\hline a. $\quad$ Is som smelter. & 0 \\
\hline b. $\quad$ Saltkrystaller som knuses. & 2 \\
\hline c. $\quad$ Ved som brenner. & 10 \\
\hline d. $\quad$ Vann som fordamper fra en vanndam. & 2 \\
\hline
\end{tabular}

Fire studenter hadde feilbesvart dette spørsmålet. Spørsmålene i tabell 5 og 6 er beslektet der begge fokuserer på forståelse av forskjellen mellom tilstandsendringer og kjemiske reaksjoner. Interessant nok så oppga samme to studenter feil svar i både tabell 5 og tabell 6. Dette øker sannsynligheten for at sammenblandingen av begreper for disse to skyldes en iboende misoppfatning og at feil avgitte svar ikke skyldes en tilfeldighet («arbeidsuhell»). I intervjuet etter undervisning om kjemiske reaksjoner så kommenterte en student:

... vann som fordamper fra en vanndam er definitivt ikke en kjemisk reaksjon så der har jeg endret oppfatning. (...) Det er vanskelig å spore til en bestemt hendelse fordi det er en kombinasjon av... det har blitt sagt en del ganger... blant annet under det der med issmeltinga... og ikke minst det der med når vi snakket om aggregattilstander.

Studenten viser her til læring om temaet og angir repetisjon og praktisk arbeid som medvirkende faktorer. Studentene hadde gjennom undervisningsperioden bl.a. jobbet praktisk med vann og ag- 
gregattilstander. I tillegg ligger det implisitt i utsagnet at summen av læring er viktig, og ikke bare én opplevd enkelterfaring.

Et annet spørsmål som dreide seg om reaktanter, produkter og forståelse av grunnstoff hadde også fire feilsvar i utvalget av 14 studenter (tabell 7).

Tabell 7. Svarfordeling fra 14 studenter der spørsmålet var hentet fra PISA-spørsmål (PISA, 2017). Korrekt alternativ er uthevet.

\begin{tabular}{|c|c|c|c|c|c|}
\hline \multicolumn{3}{|c|}{$\begin{array}{l}\text { I en gjærdeig vil gjær omdanne stivelsen og sukkeret i melet. En kjemisk reak- } \\
\text { sjon oppstår, og det vil etter hvert dannes karbondioksid og etanol. Hvor kom- } \\
\text { mer karbonatomene i karbondioksid og etanol fra? Sett en sirkel rundt «ja» } \\
\text { eller nei» for hver av følgende mulige forklaringer. }\end{array}$} & \multicolumn{3}{|c|}{$\begin{array}{l}\text { Ukorrekte svar (o) av } \\
\text { student } x, y \text { og z }\end{array}$} \\
\hline \multirow{2}{*}{$\begin{array}{l}\text { Er dette korrekt forklaring på hvor karbonatomene } \\
\text { kommer fra? }\end{array}$} & \multirow{3}{*}{$\begin{array}{ll}\text { Ja } \\
13\end{array}$} & \multirow{3}{*}{$\begin{array}{c}\text { Nei } \\
1 \\
\end{array}$} & \multicolumn{3}{|c|}{ Student } \\
\hline & & & $\mathbf{x}$ & y & $\mathbf{z}$ \\
\hline Noen karbonatomer kommer fra sukkeret. & & & o & & \\
\hline Noen karbonatomer kommer fra saltet. & 2 & 12 & o & & o \\
\hline Noen av karbonatomene kommer fra vannet. & 1 & 13 & & 0 & \\
\hline
\end{tabular}

Disse fire ukorrekte avkrysningene ble gjort av 3 studenter der én student gjorde to feilavkrysninger (student x). Ved intervjuer i etterkant av undervisningen så kom det fram at også her lå det misoppfatninger til grunn for feil avgitt svar. En av studentene (student x) med middels forkunnskaper hadde krysset av «ja» på svaralternativ b og kommenterte det på følgende måte:

... selvfølgelig gjør det ikke det fordi natriumklorid er natrium og klor. Selv om det er en C inni der så... (.....) Det var Cen jeg tenkte på der ja - stemmer det. Jeg spekulerte litt over det. (...). Jeg stusset litt over at den inneholder en C - en karbon. Men selvfølgelig er det jo klor vet du.

Her har studenten formelen for koksalt i tankene, $\mathrm{NaCl}$. Informanten har tenkt at $\mathrm{C}$ i NaCl kunne symbolisere karbon, ikke klor. Dette er et eksempel på at vedkommende ikke har behersket symbolspråket om grunnstoffer, og at det har sporet av resonneringen ved besvaring av oppgaven.

Ett spørsmål hadde karakter av å kreve litt mer avansert forståelse av kjemiske reaksjoner (tabell 8). Av 14 informanter var det her kun fem som hadde riktig avkrysning på skjemaet.

Tabell 8. Svarfordeling for et spørsmål er hentet fra TIMSS (2017). Korrekt alternativ er uthevet.

\begin{tabular}{|c|c|c|}
\hline \multicolumn{3}{|c|}{ En blanding av jern og svovel blir varmet opp. Hva blir dannet da? } \\
\hline & rnativ & Antall svar \\
\hline a. & Ett enkelt grunnstoff. & 0 \\
\hline b. & To nye grunnstoffer. & 0 \\
\hline c. & En løsning. & 1 \\
\hline d. & En legering. & 8 \\
\hline & En kjemisk forbindelse. & 5 \\
\hline
\end{tabular}


De fleste krysset av på alternativet «legering». Dette kan forstås ut fra at læreboka de benyttet framhever at en blanding av karbon i jern gir en legering (Hannisdal og Ringnes, 2013 s. 90). Det ser ut til at betydningen av ordene «varmet opp» som kan peke mot at det skjer en kjemisk reaksjon ikke alltid trigger studentene til å ta steget videre fra at det dannes en blanding (legering) til at det skjer en kjemisk reaksjon. En av studentene med middels forkunnskaper kommenterte sitt feilsvar på følgende måte:

Vi har jo vært borti at metaller kan endre egenskaper ved å blande inn andre metaller, og det kalles da legering. Og det er nok sikkert derfor jeg har valgt legering fordi du blander inn noe annet. Du blander svovel inn i jern som metall så da. Det var sikkert slik jeg tenkte.

Dette er et vanlig kjemiforsøk i skolen som har blitt benyttet i mange land (Palmer, 1995), og TIMSS velger sannsynligvis av den grunn å inkludere spørsmålet i sin studie. Dersom man har gjort dette forsøket gjennom skolearbeidet er det gjenkjennbart, men det må anses som krevende å kunne skille mellom svaralternativene «legering» og «kjemisk forbindelse» dersom man ikke har utført det konkrete eksperimentet.

\section{Begreper}

I tillegg til studentenes direkte refleksjoner rundt spørsmålene ga intervjuene også annen interessant informasjon. Kodingen ble samlet i de tre ulike kategoriene «begreper», «misoppfatninger» og «læringshendelser» (se metode). 23 utsagn fra transkriptene ble sortert til fire koder og havnet i kategorien «begreper» (tabell 2). En informant med middels forkunnskaper kommenterte at $\mathrm{CO}_{2}$-gass kan slukke en flamme:

Karbondioksidet det...stopper reaksjon rett og slett. Stopper reaksjonen... svekker reaksjonen .. hvilket ord skal jeg bruke da? (....).

Her ser studenten ut til å mangle begreper (og forståelse) for å forklare observasjoner på makronivå ved hjelp av en modellbeskrivelse på partikkelnivå (mikronivå). Dette er også tilfellet for informanten som kom med følgende utsagn:

Jeg vet jo at flammer blusser opp ved oksygen, og $\mathrm{CO}_{2}$ består jo av oksygen også, men er det noe med karbonet da som gjør at det demper gassen - at det kveler den. (...) Jeg vet ikke helt hvor den slukker - det er bare det at man har lært seg at $\mathrm{CO}_{2}$ er en brannhemmende gass.

Manglende partikkelforståelse ligger her på to nivå der studenten kobler oksygenmolekyler i $\mathrm{O}_{2}$-gass med oksygenatomer som en del av $\mathrm{CO}_{2}$-molekylet. Forståelse for at partikler må kollidere for at det skal skje en kjemisk reaksjon er heller ikke helt tilstede. Faglig sett kan dette kan beskrives som at $\mathrm{CO}_{2}$-gass (evt. $\mathrm{CO}_{2}$-molekyler) fortrenger reaktanten $\mathrm{O}_{2}$-gass $\left(\mathrm{O}_{2}\right.$-molekyler $) \mathrm{i}$ en forbrenningsreaksjon, og reaksjonen vil dermed stoppe.

En annen kommentar fra en student med gode forkunnskaper var:

.... to forskjellige poser - en som inneholdt vann og en inneholdt en ... katalysator - var det det»?

Her sikter informanten til fenolrødt som er en syre-base-indikator i reaksjonen. I denne sammenhengen blander studenten sammen to begreper (katalysator / indikator) sannsynligvis pga. ordenes delvise lydlikhet. Begge ordene slutter på «-ator», og problemet illustrerer noe av vanskeligheten med den store begrepsmengden studenter møter i naturfaget. Denne studenten sier videre:

At det er lett å blande sammen begrep som du kan litt - de er litt like.

Dette utsagnet viser at studenten er bevisst problemet og forstår gjennom refleksjon at egen forståelse av begrepene er mangelfull.

\section{Misoppfatninger}

Til kategorien misoppfatninger var det 45 utsagn fra informantene samlet i 6 koder (tabell 2). Utsagn der mer fundamentale konsept om kjemiske reaksjoner var misforstått ble sortert til denne kat- 
egorien. Flere misoppfatninger var beslektet i innhold, og de fleste var knyttet til kommentarer av ukorrekte svar i spørreskjemaet. En kommentar som likevel er interessant å løfte fram er der en student med gode forkunnskaper kommenterte en oppgave der totalmassen før og etter en kjemisk reaksjon skulle vurderes (figur 1).

Massen til stoffene $\mathrm{A}$ og $\mathrm{B}$ måles på en vekt som vist $\mathrm{i}$ figur $\mathrm{a}$. Stoff $\mathrm{B}$ tilsettes det store begeret, slik at stoff $\mathrm{C}$ dannes. Det tomme lille begeret settes tilbake på vekta som vist på figur $b$.

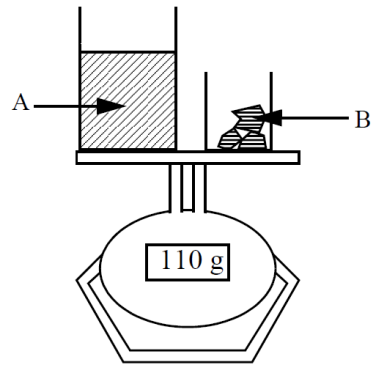

Figur a

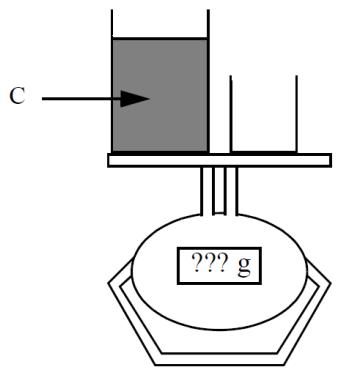

Figur b

Vekta viser $110 \mathrm{~g}$ på figur a. Hva vil den vise på figur b? Kryss av i én rute:

$$
\begin{aligned}
& \square \text { mer enn } 110 \mathrm{~g} \\
& \square 110 \mathrm{~g} \\
& \square \text { mindre enn } 110 \mathrm{~g}
\end{aligned}
$$

Figur 1. En skisse som viser ett av spørsmålene hentet fra TIMSS (2007).

Figuren antydet ikke gassdannelse i reaksjonen noe som ville medført en massereduksjon i begerglasset. Studenten skrev som kommentar:

....noe av massen vil gå tapt og gå over til energi. (...) Spesielt gass hvis det hadde blitt gass så hadde gassen fært opp - så hadde det forsvunnet masse på den måten.

For å kunne besvare spørsmålet la informanten inn informasjon i oppgaven som ikke lå der i utgangspunktet, og i tillegg er ikke konseptforståelsen av hvordan masse omdannes til energi tilstede. Spørsmål om masse i en kjemisk reaksjon der gassdannelse er involvert har studenten sett før, og informanten har sannsynligvis overført ikke-relevant informasjon fra en lignende tidligere oppgave over til denne nye problemstillingen.

\section{Læringshendelser}

Gjennom intervjuene var det et mål å få et innblikk i informantenes refleksjon rundt egen læring om kjemiske reaksjoner. Kategorien «læringshendelser» samlet 40 utsagn fordelt på 6 koder (tabell 2). 11 utsagn ble samlet i de to kodene dialog (2) og praktisk arbeid (9). Læringshendelsene som studentene viste til var ikke nødvendigvis knyttet til undervisningen som hadde vært i tidsrommet mellom spørreskjemaet og intervjuet.

Ett eksempel på læring gjennom dialog kom fram der forsker gjennom intervjuet fikk informanten til å reflektere over et spørsmål som dreide seg om hvorfor en gjærdeig hever seg i ovnen. Følgende dialog fant sted: 
Student: ....kanskje du får noen andre molekyler som blir dannet, og da må jo antallet med gassmolekyler må jo øke da.

Intervjuer: ( .....) når du steker blir det veldig varmt og da dør jo gjæra ganske fort, men den hever seg likevel.

Student: Den hever seg likevel - må vel være fordi at det må være mer bevegelse i molekylene. Molekylene må bevege seg raskere!

Intervjusituasjonen ble et eksempel på læring gjennom oppklarende dialog. Dialogen stimulerer til en tankeprosess ved å klargjøre at gjærcellene er døde, og studenten forstår at de kjemiske reaksjonene i gjæra da har stoppet - så «oppdager» studenten en mer korrekt forklaring. Studenten får klart for seg sammenhengen mellom observasjoner gjort på makronivå (gjærdeigen hever seg) og en selvutviklet forklaring på mikronivå (molekylene beveger seg raskere).

Læring gjennom praktisk arbeid er et tema som ni studenter viste til. Visualisering og konkretisering i praktisk arbeid er viktig, og dette kom fram der en student framhevet styrken ved praktisk arbeid hvor det ble samlet opp produsert gass i en lynlåspose.

Jeg mener at det vises bedre at det skjer - det kommer en gass dit (....) det er noe som tar mer plass - enn det som var der fra før.»

Studenten viste til det visuelle, mens en annen student ga et eksempel på at det praktiske arbeidet har forankret kunnskapen på en mer varig form. Han sa følgende:

«.... boblene blir laget av en kjemisk reaksjon (....) Vi hadde jo et sånt forsøk for en tid tilbake (....) Enn det da? .

Studenten viste til et forsøk som ble utført ca. ett år tidligere og ble selv forbauset over at han klarte å rekapitulere det som skjedde for så å overføre og utvikle forklaringen til den nye eksperimentelle situasjonen han sto overfor.

En student hadde under praktisk arbeid fătt avlært en misoppfatning og viste til et punkt hvor han skjønte at det å løse et stoff ikke var en kjemisk reaksjon:

Når et stoff løste seg opp i vann. Da har jeg lært at det er ionene som er oppløst i vann - som ikke er et nytt stoff da. (.....) Det var først når det begynte å stå (aq) bakom formelen tror jeg. Og ikke bare sto (l).»

Studenten har tidligere lært om aggregattilstander gjennom bevisstgjøring og klargjøring av symbolbruken (aq) og (1). Symbolene benyttes svært mye i kjemiske reaksjonsligninger, og en bevisstgjøring i læringsprosessen om dette er viktig da symbolbruken kan være forvirrende for studenter og elever.

\section{DISKUSJON}

Lærerstudentene som skal ut og undervise naturfag i grunnskolen må opparbeide seg et kunnskapsnivå som ligger godt over hva 15-åringer er ment å skulle beherske. Studentene i denne studien har etter det 15-årige skolenivået (9. klasse) gjennomgått 2 til 4 år med naturfag- og kjemiundervisning. De har i tillegg valgt naturfag som fordypningsemne i lærerstudiet sitt. Et bredt miljø av fagpersoner fra flere land har med utgangspunkt i nasjonale læreplaner gjennom PISA- og TIMSS-spørsmål indirekte vært med på å definere forventet kunnskapsnivå innen naturfagene blant 15-åringer (PISA, 2017; TIMSS, 1995, 2007, 2015 og 2017). Et utvalg av spørsmål fra PISA og TIMSS ble derfor grunnlaget for spørreskjemaet i denne studien om kjemiske reaksjoner, og det er av interesse å se på studentenes forkunnskaper og misoppfatninger om kjemiske reaksjoner på dette nivået. Økt kunnskap om dette er av verdi både for selve undervisningen på utdanningsnivå universitet og høgskole, og kunnskapen har en tilleggsverdi for studentene som skal ut i grunnskolen som naturfaglærere etter hvert. 
En gjennomgang av studentens svar på flervalgsoppgavene viste at begreper var problematiske for mange av studentene. Begrepsforståelse er helt grunnleggende og kritisk for læring, og kan bli undervurdert som en viktig forutsetning for dypere kjemilæring. Dette er i god overenstemmelse med tidligere studier som påpeker at undervisning i kjemi har en stor kommunikasjonsutfordring (Fensham, 2002). Studentene har problemer med å skille kjemiske og fysiske egenskaper til stoffer (tabell 3), og en gryende erkjennelse av hva forskjellene innebærer ser ut til å oppstått for en student etter undervisningsperioden om kjemiske reaksjoner. Videre har halvparten av informantgruppen ikke klart for seg forskjellen på atomer og molekyler - selve begrepene på partikkelnivå ser ut til å være uklare (tabell 4). Dette er ikke-observerbare enheter, og modeller og abstrahering er nødvendig for å øke forståelsen av begrepene. Innlæring av slike begrep er krevende, og kan raskt gi grunnlag for sammenblanding og forvirring (Barke et al., 2009; Bravo, Cervetti, Hiebert \& Pearson, 2006). I skolen benyttes ofte begrepet «partikler» om både ioner, atomer og molekyler, og partikkelmodellen nevnes eksplisitt i LK-06 som kompetansemål etter 7- årstrinn (Udir, 2019 a). Dette er ment å være en forenklende strategi, men det kan også bygge opp om misoppfatninger der man i undervisning i for stor grad unnlater å skille mellom atom og molekyl, og i stedet benytter det enklere og mindre presise begrepet partikkel. En student unngår i intervjusituasjonen bruk av fagterminologi ved å innføre «det» og «ting» om vev molekyler, mineraler og planter/dyr. Denne begrepsusikkerheten er illustrativ, og begrepsusikkerhet er hemmende som utgangspunkt for videre læring i naturfaget (Bravo et al., 2006).

Et annet fenomen som dukket opp som en potensiell bremsekloss for begrepslæring er sammenblanding av begreper med delvis lydlikhet. En student blandet sammen begreper som var delvis lydlike ( «katalysator» og «indikator»), og informanten var selv klar over at dette var et problem. Ord som ligner eller høres ut som andre ord er problematiske i begrepslæring, og sammenblandinger kan lett oppstå (Cassels \& Johnstone, 1985). En didaktisk bevissthet rundt dette som lærer er viktig.

Manglende dybdeforståelse av partikler blir også illustrert der en student har lært at $\mathrm{CO}_{2}$ er en brannhemmende gass, men klarer ikke å forklare hvorfor $\mathrm{CO}_{2}$-gassen kveler flammen. Dette er et klassisk eksempel på at kjemiforståelsen ikke lett går fra makronivå (brannhemmende gass) til mikronivå ( $\mathrm{CO}_{2}$-molekyler fortrenger $\mathrm{O}_{2}$-molekyler i forbrenningsreaksjonen). God forståelse for overgangen mellom makro- og mikronivå er en av de store læringsbarrierene innen kjemifaget, og denne læringsbarrieren er noe en lærer bør være svært oppmerksom på (Johnstone, 1991). Studentens forståelse for forbrenningsreaksjonen ut til å være strandet på makronivå, og en helhetlig forståelse som involverer makronivå, mikronivå og symbolbruk er ikke etablert. Ifølge Johnstone (1991) sin teori om kjemifagets tre dimensjoner kan dette skyldes en undervisning der lærerens forklaringer raskt beveger seg mellom disse tre dimensjonene uten å gå grundig inn på hvert nivå før neste nivå i forklaringsmodellen blir introdusert. Undervisning der disse overgangene ikke blir grundig og godt ivaretatt er svært vanlig og en av de store fallgruvene innen kjemiundervisning.

Et overraskende funn var at tre studenter ikke koblet begrepene «kjemisk reaksjon» med «kjemisk forandring». En av studentene klarte til og med å identifisere opprinnelsen til begrepsforvirringen. I introduksjonsdelen av studentenes lærebok om kjemiske reaksjoner (kapittel 6) benytter forfatterne konsekvent terminologien kjemiske reaksjoner og fysiske forandringer (Hannisdal og Ringnes, 2013 s. 135). Dette er til og med framhevet i en overskrift. Begrepsforvirringen kan med andre ord være generert av læreboka der ordet «forandring» er reservert fysiske forandringer, mens TIMSS-spørsmålet benytter begrepskoblingen «kjemiske forandringer». De samme forfatterne diskuterer faktisk muligheten for at lærebøker kan generere misoppfatninger gjennom misvisende figurbruk o.l. (Ringnes \& Hannisdal, 2014 s. 74)! Dette føyer seg inn i tidligere studier der lærebøker er kritisert for upresise beskrivelser som kan lede til misoppfatninger (Stojanovska, Petrusevski \& Soptrajanov, 2012).

En annen misoppfatning som dukket opp i studien kom fra en student som hevdet at det var massereduksjon i løpet av en kjemisk reaksjon. Hverken gassdannelse, varmeopptak eller varmeavgivelse var spesifisert i oppgaven, og studenten begrunnet svaret med at han baserte seg på erfaringer med tidligere «lignende oppgaver» og antok gassproduksjon for å forklare at han mente at massen i reak- 
sjonsbeholderen avtok. Dette gir mening, men studenten sa i tillegg at det ble avgitt varme noe som han også mente ga massetap. Det siste er en misoppfatning om eksoterme reaksjoner som kan oppstå f.eks. ved observasjon av et stearinlys som brenner og som gir et tilsynelatende massetap («lyset kommer bort»), og det er en vanlig misoppfatning (Kind, 2004). En annen mulig tolkning av siste utsagn er at studenten blander den kjemiske reaksjonen med varmeavgivelse og massetap som man kan få ved kjernefysiske reaksjoner.

Studentenes refleksjoner rundt egne feilsvar og misoppfatninger ga et grunnlag for å identifisere hva som var kilde til oppklaring av misoppfatninger rundt temaet kjemiske reaksjoner. Studien hadde som ett av målene å kunne identifisere gode læringsøyeblikk eller viktige faktorer for læring om kjemiske reaksjoner. Slik kunnskap er verdifull for den som underviser kjemi, og det har overføringsverdi til studentenes framtidige profesjonsrolle som naturfaglærer. En student forstår gjennom selve intervjuet at en gjærdeig hever seg i ovnen fordi $\mathrm{H}_{2} \mathrm{O}-\mathrm{og} \mathrm{CO}_{2}-$ molekyler beveger seg raskere. Dialogen i intervjuet utviklet seg til en oppklarende læringsprosess og er et eksempel på at innspill fra «lærer» (intervjuer) stimulerte studenten til utvikling av egen forståelse av sammenhengen mellom molekylbevegelse og temperatur. Denne dialogformen kan kalles refleksjonsdialog (Kolstø, 2016) og er i samsvar med Wells og Arauz (2006) som påpeker viktigheten av at studenter gjennom dialog aktivt involveres i bygging av meningsinnhold av begreper.

Omfang og form på praktisk, eksperimentelt arbeid i naturfagundervisningen er omdiskutert (Abrahams \& Millar, 2008; Kjærnsli, Lie, Olsen, \& Roe, 2007 s. 115). Det er mye som tyder på at en utforskende tilnærming er en god vei å gå for å oppnå mer langsiktig læring (Knain \& Kolstø, 2019). Ni studenter i denne studien framhevet læring ved praktisk arbeid som noe positivt, og styrken ved det visuelle ble framhevet (f.eks. gassdannelse i en lynlåspose). En interessant observasjon var at en student klarte å resonnere seg fram til en forklaring på gassdannelse ved å overføre læring fra et forsøk han hadde vært med på ett år tidligere (!). Dette er overføring av kunnskap fra en tidligere læringssituasjon over til anvendelse på et nytt problem, og det faller inn under forståelsen av begrepet «dybdelæring» som framheves i Fagfornyelsen, ny læreplan for grunnskolen (Udir, 2019b; Voll \& Holt, 2019).

Et interessant innspill kom fra en informant som lærte forskjellen mellom stoff løst i vann og stoff i væskefase gjennom å fokusere på hva symbolene (aq) og (l) betydde. Symbolbruk er ofte antatt å være krevende (Barke et al., 2009), men istedenfor å omgå symbolbruk eller ta lett på det, så er dette et eksempel på at man bør være bevisst bruken av symboler, og at symbolbruk aktivt kan benyttes i læringsøyemed. Tilstandssymboler er relativt intuitive og forklarende og kan med fordel i større grad bevisst benyttes i undervisning, spesielt på nivå videregående skole og oppover (Ringnes og Hannisdal, 2014).

Et annet interessant sammenblanding var at en informant knyttet bokstaven «C» i NaCl til symbolet $\mathrm{C}$ for karbon. Koblingen mellom mikronivået (karbonatomer) og symbolspråket (NaCl) er ikke er etablert (Johnstone, 1991), og studenten synliggjør usikkerheten ved å si «en karbon» og ikke et karbonatom. Tilleggsordet atom er presiserende, og i undervisningssammenheng og i kjemifaglige diskusjoner er det viktig å benytte tilleggsord for å presisere hvilket nivå man snakker om (Ringnes og Hannisdal, 2014).

Denne studien har identifisert tidligere kjente misoppfatninger om kjemiske reaksjoner som forveksling med aggregattilstander, bevaring av masse, blandinger, fysisk-kjemiske egenskapet etc. Andre enkeltfunn er nye som f.eks. innen representasjon ( $\mathrm{C}$ i NaCl forveksles med $\mathrm{C}$ for karbon), og en overraskende lærebokgenerert misoppfatning har blitt identifisert (begrepet forandring ble ikke forstått). Studentene identifiserte videre dialog, praktisk arbeid og bevisst symbolbruk som viktig for sin egen læring om kjemiske reaksjoner. Funnene har betydning for kjemiundervisning generelt og kjemiundervisning i lærerutdanning spesielt. Det sistnevnte er begrunnet med at det faglige nivået de utvalgte spørsmålene ligger på er det samme nivået som lærerstudentene skal undervise på når de kommer ut som yrkesutøvere i grunnskolen. 
Studien viser at studentene med 2-4 års undervisning i kjemi- og naturfag utover «nivå 15 år» fortsatt besitter en del misoppfatninger som 15-åringer er ment å skulle beherske definert ut fra PISA og TIMSS. Det var derfor overraskende at misoppfatninger på dette fagnivået var så utbredt. Disse studentene skal etter endt utdanning ut og undervise elever opp til 16 år innen naturfag og kjemi, og det er derfor nyttig for lærerutdannere å bli oppmerksom på dette faggapet som universitetene må fylle. Vi har studert et avgrenset område i kjemien i en kort tidsperiode. Denne studien har en generaliserende karakter gjennom å støtte opp om andres tilsvarende funn og er dermed et bidrag til å bygge et fundament til en bredere teori om misoppfatninger og læring om kjemiske reaksjoner (Firestone, 1993). Ved videre forskning vil det være interessant med en kvantitativ tilnærming, og lengre tidsstudier kan gi mer innsikt i denne læringsproblematikken og undervisning. En kvantitativ studie kan bidra til mere generalisering, og i kjemien kan det også være problematiske begrep og tema hos studentene som ennå er ikke er avdekket. Avdekking av misoppfatninger som oppstår systematisk kan gi kjemiundervisningen en ny didaktisk/metodisk retning.

Et område som kan være særlig aktuelt å styrke er å arbeide mere og annerledes med å konseptuelt integrere makro-, mikro- og symbolnivåforståelsen (Jaber \& BouJaoude, 2012). Det at man underviser kjemi ved raske skifter mellom kjemifagets tre nivå har vist seg seg å være lite hensiktsmessig (Johnstone, 1991), og hvorfor skal man introdusere alle tre nivå samtidig til unge mennesker? Forklaringer på observasjoner gjort på makronivå kan bli presentert etter individuelle behov og i små doser, og kanskje skal noen elever ikke utfordres til å oppnå forståelse på alle tre nivå? Videre forskning på dette er under planlegging av oss der bl.a en metodisk tilnærming som «lesson study» er aktuell (Carrier, 2011).

\section{REFERANSER}

Abrahams, I. \& Millar, R. (2008). Does Practical Work Really Work? A study of the effectiveness of practical work as a teaching and learning method in school science. International Journal of Science Education, 1-25. doi:10.1080/09500690701749305

Adzape, J. N. \& Akpohol, T. V. (2015). Correcting students' chemical misconceptions based on two conceptual change strategies and their effect on their achievement. IOSR Journal of Research \& Method in Education, 5(6), 58-65. doi:10.9790/7388-05615865

Barke, H.-D., Hazari, A. \& Yitbarek, S. (2009). Misconceptions in chemistry - addressing perceptions in chemical education. Springer Verlag Berlin Heidelberg. doi:10.1007/978-3-540-709893

Braun, V. \& Clarke, V. (2006). Using thematic analysis in psychology. Qualitative Research in Psychology, 3, 77-101. doi:10.1191/1478088706qpo630a

Bravo, M. A., Cervetti, G. N., Hiebert, E. A. \& Pearson, P. D. (2006). From passive to active control of science vocabulary. In: D. W. Rowe, R. T. Jimenez, D. L. Compton, D. K. Dickinson, Y. Kim, K. M. Leander \& V. J. Risko (Eds). $56^{\text {th }}$ Yearbook of the National Reading Conference, pp. 264275 .

Butler, J., Simmie, G. M. \& O’Grady, A. (2015). An investigation into the prevalence of ecological misconceptions in upper secondary students and implications for pre-service teacher education. European Journal of Teacher Education, 38(3), 300-319. doi:10.1080/02619768.2014.943394

Calik, M. \& Ayas, A. (2005). A comparison of level of understanding of eight-grade students and science student teachers related to selected chemistry concepts. Journal of Research in Science Teaching, 42(6), 638-667. doi:10.1002/tea.20076

Carrier, S. J. (2011). Implementing and integrating effective teaching strategies including features of lesson study in an elementary science methods course. The teacher educator, 46(2): 145-160. doi:10.1080/08878730.2011.552666

Cassels, J. \& Johnstone, A. (1985). Words that matter in science. London: Royal Society of Chemistry. 
de Vos, W., van Berkel, B. \& Verdonk, A. H. (1994). A coherent conceptual structure of the chemistry curriculum. Journal of Chemical Education, 71(9), 743-746. doi:10.1021/edo71p743

Düsing, K., Asshoff, R. \& Hammann, M. (2019). Tracing matter in the carbon cycle: zooming in on high-school students' understanding of carbon compounds and their transformations. International Journal of Science Education, 41(17), 2484-2507. doi:10.1080/09500693.2019.1686665

Fensham, P. J. (2002). Implications, large and small, from chemical education research for the teaching of chemistry. Química Nova, 25(2), 335-339. doi:10.1590/So10040422002000200024

Firestone, W. A. (1993). Alternative arguments for generalizing from data as applied to qualitative research. Educational Researcher, 22(4), 16-23. doi:10.3102/0013189X022004016

Gabel, D. (1999). Improving teaching and learning through chemistry education research: A look to the future. Journal of Chemical Education 76(4), 548-554. doi:10.1021/edo76p548

Gönen, S. (2008). A study on student teachers' misconceptions and scientifically acceptable conceptions about mass and gravity. Journal of Science Education and Technology 17, 70-81. doi: 10.1007/s10956-007-9083-1

Hannisdal, M. \& Ringnes, V. (2013). Kjemi for lærere. Naturfag i grunnskolelærerutdanningen 5.-10. trinn. Gyldendal akademisk.

Haug, B. (2017). Spørsmål knyttet til temaet kjemiske endringer. Naturfagsenteret - nasjonalt senter for naturfag i opplæringa.

Håland, B. (2010). Student teacher conceptions of matter and substances - evaporation and dew formation. NorDiNa 6(2), 109-124. doi:10.5617/NORDINA.251

Ilyas, A. \& Saeed, M. (2018). Exploring teachers' understanding about misconceptions of secondary grade chemistry students. International Journal for Cross-Disciplinary Subjects in Education, 9, 3323-3328. doi:10.20533/ijcdse.2042.6364.2018.0444

Jaber, L. Z. \& BouJaoude, S. (2012). A macro-micro-symbolic teaching to promote relational understanding of chemical reactions. International Journal of Science Education, 34(7), 973-998. doi :10.1080/09500693.2011.569959

Johnstone, A. H. (1991). Why is science difficult to learn? Things are seldom what they seem. Journal of Computer Assisted Learning 7(2), 75-83. doi:10.1111/j.1365-2729.1991.tboo230.x

Jong, O. D. \& Taber, K. S. (2014). The many faces of high school chemistry. In: Lederman, N. G. and Abell, S. K.: Handbook on Research on Science Education. Vol. II. Routledge: pp. 457-48o. doi:10.4324/9780203097267-33

Kind, V. (2004). Beyond Appearances: Students' Misconceptions About Basic Chemical Ideas. A report to the royal society of chemistry. $2^{\text {nd }}$ edit.

Kjærnsli, M., Lie, S.V, Olsen, R. G. \& Roe, A. (2007). Tid for tunge løft. Norske elevers kompetanse i naturfag, lesing og matematikk i PISA 2006. Universitetsforlaget.

Knain, E. \& Kolstø, S. D. (2019). Utforskende arbeidsmåter - en oversikt. I: Knain, E. og Kolstø, S. D. (red). Elever som forskere i naturfag. 2. utg. Universitetsforlaget.

Kolstø, S. D. (2016). Lærerledet dialog kan fremme elevers kunnskapsutvikling. I: Thorsheim, F., Kolstø, S. D og Andresen, M. U. (Eds.) I: Erfaringsbasert læring. s. 169-197.

Kolstø, S. D. (2018). Use of dialogue to scaffold students' inquiry-based learning. NorDiNa, 14(2), 154-169. doi:10.4617/nordina.6164

Kula, S. \& Güzel, E. B. (2014). Misconceptions emerging in mathematics student teachers' limit instruction and their reflections. Quality and Quantity, 48, 3355-3372. doi:10.1007/s11135-0139961-y

Kvale, S. \& Brinkmann, S. (2015). Det kvalitative forskningsintervju. Gyldendal akademiske, 3. utgave.

Minner, D. D., Levy, A. J. \& Century, J. (2010). Inquiry-based science instruction - what is it and does it matter? Results from a research synthesis years 1984 to 2002. Journal of Research in Science Teaching, 47(7), 474-496. doi:10.1002/tea.20347 
Palmer, W. P. (1995). Physical and chemical change: the long history of the iron filings and sulfur experiment. Proceedings of the Third International History, Philosophy and Science Teaching Conference, Minneapolis, Minnesota, USA, 2, pp. 939-949.

Phelps, A. J. (1996). Teaching to enhance problem solving: It's more than numbers. Journal of Chemical Education, 73(4): 301-304. doi:10.1021/edo73p301

PISA (2017). Programme for International Student Assessment. http://www.uv.uio.no/ils/forskning/prosjekt-sider/pisa/frigitte-oppgaver/ Hentet ut 10. desember 2017.

Ringnes, V. \& Hannisdal, M. (2014). Kjemi fagdidaktikk - kjemi i skolen. 3. utg. Cappelen Damm.

Stojanovska, M. I., Petrusevski, V.M., Soptrajanov, B. T. (2012). Addressing students' misconceptions concerning chemical reactions and symbolic representations. Bulgarian Journal of Science Education, 21(6):829-852.

Taber, K. (2002). Chemical misconceptions - prevention, diagnosis and cure volume 1. Theoretical background. Royal society of chemistry.

Teed, R. \& Slattery, W. (2011). Changes in geologic time understanding in a class for preservice teachers. Journal of Geoscience Education 59(3): 151-162. doi:10.5408/1.3604829

TIMSS (1995, 2007, 2015, 2017). Trends in International Mathematics and Science Study. http:// www.timss.no/timsso5_frigitte.html Hentet ut 10. desember 2017.

Udir (2019 a). Kunnskapsløftet - læreplan for norsk grunnskole: https://www.udir.no/laring-ogtrivsel/lareplanverket/ Hentet ut 9. oktober 2019.

Udir (2019 b). Fagfornyelsen - læreplan for norsk grunnskole. Overordnet del: https://www.udir. no/laring-og-trivsel/lareplanverket/fagfornyelsen/ Hentet ut 16. oktober 2019.

Voll, L. O. \& Holt, A. (2019). Dybdelæring i naturfag. I: Voll, L. O., Øyehaug, A. B. og Hold, A. E. (red.). Dybdelæring i naturfag. Universitetsforlaget. s. 17-36.

Wells, G. \& Arauz, R. M. (2006). Dialogue in the classroom. Journal of the Learning Sciences, 15(3): 379-428. doi:10.1207/s15327809jls1503_3 